\title{
Seasonal Characteristics of the Chemical Composition of Fine Particles in Residences of Nanjing, China
}

\author{
Guozhi Cao ${ }^{1,2}$, Jun Bi ${ }^{1,3}$, Zongwei Ma ${ }^{1,3, *}$, Zhijuan Shao ${ }^{1, * \mathbb{C}}$ and Jinnan Wang ${ }^{1,2}$ \\ 1 State Key Laboratory of Pollution Control \& Resource Reuse, School of the Environment, Nanjing University, \\ Nanjing 210023, China; caogz@caep.org.cn (G.C.); jbi@nju.edu.cn (J.B.); wangjn@caep.org.cn (J.W.) \\ 2 State Environmental Protection Key Laboratory of Environmental Planning and Policy Simulation, \\ Chinese Academy for Environmental Planning, Beijing 100012, China \\ 3 Jiangsu Collaborative Innovation Center of Atmospheric Environment and Equipment Technology, \\ Nanjing University of Information Science \& Technology, Nanjing 210044, China \\ * Correspondence: zma@nju.edu.cn (Z.M.); shaozhijuan@126.com (Z.S.)
}

Received: 3 January 2019; Accepted: 21 March 2019; Published: 25 March 2019

\begin{abstract}
Indoor fine particulate matter $\left(\mathrm{PM}_{2.5}\right)$ and its chemical composition is important for human exposure as people spend most of their time indoors. However, few studies have investigated the multiseasonal characteristics of indoor $\mathrm{PM}_{2.5}$ and its chemical composition in China. In this study, the chemical composition of $\mathrm{PM}_{2.5}$ samples in residences was analyzed over four seasons in Nanjing, China. Indoor water-soluble ions exhibited similar seasonal variations (winter $>$ autumn $>$ summer $>$ spring) to those from outdoors (winter $>$ autumn $>$ spring $>$ summer) except in summer. Whereas, indoor metallic elements exhibited a different seasonal pattern from that of outdoors. The highest concentrations of indoor metallic elements were observed in summer when the outdoor concentrations were low. The different seasonal variations of the chemical composition between indoor and outdoor $\mathrm{PM}_{2.5}$ indicated that people should consider both indoor and outdoor sources to reduce their exposure to air pollutants in different seasons. The carcinogenic risks for metallic elements were within the acceptable levels, while manganese $(\mathrm{Mn})$ was found to have potential noncarcinogenic risk to humans. More attention should be paid to the pollution of $\mathrm{Mn}$ in the study area in the future. Moreover, the cumulative effect of noncarcinogenic $\mathrm{PM}_{2.5}$-bound elements should not be ignored.
\end{abstract}

Keywords: metallic elements; water-soluble ions; seasonal variation; indoor air quality; health risk assessment

\section{Introduction}

With the development of the economy and population, developing countries, such as China, are now facing increasing air pollution. In 2017, the air quality in more than $70 \%$ of Chinese cities exceeded the National Air Quality Standard, with ambient fine particulate matter $\left(\mathrm{PM}_{2.5}\right)$ as the dominant air pollutant [1]. $\mathrm{PM}_{2.5}$ had been identified as one of the leading risk factors for global disease [2]. Exposure to $\mathrm{PM}_{2.5}$ has been shown to have associations with adverse health effects in epidemiological studies, such as cardiovascular and respiratory diseases, cancer, and preterm birth [3-6]. The degree of $\mathrm{PM}_{2.5}$-related toxicity mainly depends on its chemical components, including water-soluble inorganic ions, metallic elements, and organic and elemental carbon [7]. Water-soluble inorganic ions, such as sodium $\left(\mathrm{Na}^{+}\right)$, potassium $\left(\mathrm{K}^{+}\right)$, calcium $\left(\mathrm{Ca}^{2+}\right)$, ammonia $\left(\mathrm{NH}_{4}^{+}\right)$, nitrate $\left(\mathrm{NO}_{3}{ }^{-}\right)$, chloride $\left(\mathrm{Cl}^{-}\right)$, and sulfate $\left(\mathrm{SO}_{4}{ }^{2-}\right)$, were found to be the main components of $\mathrm{PM}_{2.5}$ and act as surface active reagents, which increase the toxicity of noxious organic substances [8]. The other main components that determine the toxicity of $\mathrm{PM}_{2.5}$ are metallic elements, such as lead $(\mathrm{Pb})$, manganese $(\mathrm{Mn})$, copper $(\mathrm{Cu})$, 
chromium (Cr), arsenic (As), and cadmium (Cd), which can cause detrimental health impacts to human respiratory, cardiovascular, and nervous systems [9-11]. Understanding the chemical characteristics of $\mathrm{PM}_{2.5}$ concentrations is necessary to reduce its adverse impact on human health.

Many studies, which focused on the concentrations, species, spatial-temporal variations, and source identification, have investigated the components of ambient $\mathrm{PM}_{2.5}$ in Chinese cities and provided suggestions for ambient $\mathrm{PM}_{2.5}$ reduction [12-14]. Ambient $\mathrm{PM}_{2.5}$ component data have been widely used in human exposure and health risk assessments [15-17]. However, concentrations of ambient $\mathrm{PM}_{2.5}$ and its components cannot completely represent human exposure concentrations as people spend approximately $80 \%-90 \%$ of their times indoors, such as in residences, offices, vehicles, and classrooms [18-20]. Indoor $\mathrm{PM}_{2.5}$ can arise from both outdoor sources (e.g., traffic, industry and heating emissions) and indoor sources (e.g., cooking, smoking, and resuspension during indoor activities) [21]. Therefore, the concentrations of indoor $\mathrm{PM}_{2.5}$ and its chemical components may differ from the outdoors, which may lead to a bias in health effect assessments [22-24]. In this context, research on indoor $\mathrm{PM}_{2.5}$ and its chemical components is helpful for improving the accuracy of exposure and health effect estimates.

Due to the importance of indoor exposure, studies of indoor $\mathrm{PM}_{2.5}$ and its effect on human health have received more and more attention in recent years. Many related studies have been performed to investigate indoor $\mathrm{PM}_{2.5}$ in China $[25,26]$. The concentration of $\mathrm{PM}_{2.5}$ and its chemical components were investigated in some studies, and differences between indoors and outdoors were observed, depending on the seasons [27-29], indoor activities [27,30], ventilation systems [31], cooking fuels [26], etc. However, most of the studies were conducted in a single season or during specific periods (e.g., heating seasons or heavy haze-fog episodes) [32-34]. Few studies investigated the seasonal variation of chemical compositions of $\mathrm{PM}_{2.5}$ in a single family [29], which may not be representative. To our knowledge, little is known about the multiseasonal characteristics of the chemical components of $\mathrm{PM}_{2.5}$ in multiple residences in China.

To fill this gap in the knowledge, we conducted a study in multiple residences of Nanjing, China, to characterize the concentration and chemical composition (water-soluble inorganic ion and metallic element content) in indoor and outdoor $\mathrm{PM}_{2.5}$ samples over four seasons. The objectives of the study were to examine the multiseasonal characteristics of chemical-species in indoor $\mathrm{PM}_{2.5}$ and explore the indoor and outdoor difference. The health risk of toxic elements in $\mathrm{PM}_{2.5}$ was assessed for adults and children. The results of this study will provide important implications for improving indoor air quality in residences and reduce human exposure and health impacts.

\section{Materials and Methods}

\subsection{Study Area}

Nanjing, a city located in the eastern part of China ( $\left.\mathrm{N} 31^{\circ} 14^{\prime} \sim 32^{\circ} 37^{\prime}, \mathrm{E} 118^{\circ} 22^{\prime} \sim 119^{\circ} 14^{\prime}\right)$, is an important central city in the Yangtze River Delta region. The climate is subtropical, with hot summers, cold winters, and comfortable transitional seasons (spring and autumn). The city of Nanjing has a population of over $8,200,000$. The air pollution in Nanjing is serious, with $\mathrm{PM}_{2.5}$ as one of the primary pollutants. In 2016, the ambient air quality index was rated excellent or good for $66.1 \%$ with an annual $\mathrm{PM}_{2.5}$ concentration of $47.9 \mu \mathrm{g} / \mathrm{m}^{3}$ [35], which is much higher than the annual mean standard $\left(35 \mu \mathrm{g} / \mathrm{m}^{3}\right)$ of the National Ambient Air Quality Standards of China.

\subsection{Sampling Sites}

The study was conducted from March 2016 to February 2017. A total of 124 homes participated in the study, with 34 homes in spring, 35 in summer, 20 in autumn, and 35 in winter. The details of the process of home recruitment were described by Shao et al. [36]. All the homes that participated in this study were apartments in urban areas with no obvious industrial sources around. The details of the home characteristics are shown in Table 1. A brief description of the sampling approach is included 
as follows. Indoor and outdoor $\mathrm{PM}_{2.5}$ concentrations were measured simultaneously by personal exposure micromonitors (MicroPEM; RTI International, Research Triangle Park, NC, USA). The indoor monitors were placed in the living room of each family, approximately $1.5 \mathrm{~m}$ above the ground, while the outdoor measurements were taken on the open balcony outside of the home. Two continuous 24-hour indoor and outdoor measurements were taken simultaneously at each home. The real-time concentrations of $\mathrm{PM}_{2.5}$ were recorded every $10 \mathrm{~s}$ by the MicroPEM. The poly tetra fluoroethylene PTFE filters ( $25 \mathrm{~mm}, 3.0 \mathrm{~mm}$ pore size, PALL, NewYork, NY, USA) in the MicroPEMs were replaced by our researchers every $24 \mathrm{~h}$. The two filters obtained from each home were then taken to the laboratory of Nanjing University for water-soluble inorganic ion and metallic element analysis.

Table 1. Descriptions of home characteristics.

\begin{tabular}{|c|c|c|c|c|c|}
\hline \multicolumn{2}{|l|}{ Variables } & \multirow{3}{*}{$\begin{array}{c}\text { Spring } \\
N(\%)\end{array}$} & \multirow{3}{*}{$\begin{array}{c}\begin{array}{c}\text { Summer } \\
N(\%)\end{array} \\
16(45.7) \\
19(54.3)\end{array}$} & \multirow{3}{*}{$\begin{array}{c}\text { Autumn } \\
N(\%)\end{array}$} & \multirow{3}{*}{$\begin{array}{c}\text { Winter } \\
N(\%)\end{array}$} \\
\hline & Multi-story & & & & \\
\hline Building Height & High-rise & & & & \\
\hline \multirow{4}{*}{ Construction date } & Before 1990 & $6(17.6)$ & $6(17.1)$ & $3(15.0)$ & $5(14.3)$ \\
\hline & 1991-2000 & $5(14.7)$ & $4(11.4)$ & $5(25.0)$ & $9(25.7)$ \\
\hline & $2001-2010$ & $5(14.7)$ & $7(20.0)$ & $5(25.0)$ & $10(28.6)$ \\
\hline & After 2011 & $18(52.9)$ & $18(51.4)$ & $7(35.0)$ & $11(31.4)$ \\
\hline \multirow{4}{*}{ Floor area } & $<60 \mathrm{~m}^{2}$ & $5(14.7)$ & $7(20.0)$ & $3(15.0)$ & $9(25.7)$ \\
\hline & $60-90 \mathrm{~m}^{2}$ & $15(44.1)$ & $13(37.1)$ & $8(40.0)$ & $16(45.7)$ \\
\hline & $90-120 \mathrm{~m}^{2}$ & $11(32,4)$ & $12(34.3)$ & $7(35.0)$ & $6(17.1)$ \\
\hline & $>120 \mathrm{~m}^{2}$ & $3(8.8)$ & $3(8.6)$ & $2(10.0)$ & $4(11.4)$ \\
\hline \multirow{2}{*}{ Building orientation } & North-South & $21(61.8)$ & $25(71.4)$ & $12(60.0)$ & $24(68.6)$ \\
\hline & Other & $13(38.2)$ & $10(28.6)$ & $8(40.0)$ & $11(31.4)$ \\
\hline \multirow{3}{*}{$\begin{array}{l}\text { Distance to the main } \\
\text { traffic Road }\end{array}$} & $<100 \mathrm{~m}$ & $12(35.3)$ & $16(45.7)$ & $13(65.0)$ & $15(42.9)$ \\
\hline & $100-500 \mathrm{~m}$ & $13(38.2)$ & $13(37.1)$ & $5(25.0)$ & $13(37.1)$ \\
\hline & $500-1000 \mathrm{~m}$ & $9(26.5)$ & $6(17.1)$ & $2(10.0)$ & $6(17.1)$ \\
\hline \multirow{2}{*}{ Dwelling ownership } & Owner & $28(82.4)$ & $28(80.0)$ & $13(65.0)$ & $30(85.7)$ \\
\hline & Tenant & $6(17.6)$ & $7(20.0)$ & $7(35.0)$ & $5(14.3)$ \\
\hline \multirow{4}{*}{ Number of occupants } & $\leq 1$ & $2(5.9)$ & $1(2.90)$ & $1(5.0)$ & $2(5.7)$ \\
\hline & $2-3$ & $15(44.1)$ & $16(45.7)$ & $6(30.0)$ & $14(40.0)$ \\
\hline & $4-5$ & $17(50.0)$ & $17(48.6)$ & $13(65.0)$ & $18(51.4)$ \\
\hline & $\geq 6$ & - & $1(2.9)$ & - & $1(2.9)$ \\
\hline
\end{tabular}

\subsection{Water-Soluble Ions Analysis}

One of the two PTFE filters obtained from each sampling home was used to analyze the concentrations of water-soluble inorganic ions, including five cations $\left(\mathrm{Na}^{+}, \mathrm{K}^{+}, \mathrm{Ca}^{2+}, \mathrm{Mg}^{2+}, \mathrm{NH}_{4}^{+}\right)$ and three anions $\left(\mathrm{NO}_{3}{ }^{-}, \mathrm{Cl}^{-}, \mathrm{SO}_{4}{ }^{2-}\right)$. Each filter was cut into four slices and put in a centrifuge tube. $10 \mathrm{~mL}$ of ultra-pure water (specific resistance $\geq 18 \Omega \mathrm{cm}$ ) was added to it. Then, the water-soluble ions were extracted by ultrasound for $30 \mathrm{~min}$ in a lower temperature. The extractions were filtered through a micro-porous membrane (pore size, $0.45 \mu \mathrm{m}$; diameter, $25 \mathrm{~mm}$ ), and transferred to clean plastic bottles. The filtrates were stored in the refrigerator at $4{ }^{\circ} \mathrm{C}$ until analysis. Blank filters were also analyzed in the same way as samples, and the values were subtracted from the sample results.

An ion chromatography instrument (ICS-1000, Dionex, Sunnyvale, CA, USA) operating at a flow rate of $1.0 \mathrm{~mL} / \mathrm{min}$ was used to analyze the eight inorganic ions in $\mathrm{PM}_{2.5}$. The standard solution for water-soluble inorganic ions was purchased from the Research Center of China National Standard Reference Materials. The standard solution was diluted by ultra-pure water to mass concentrations of $0.00,0.20,0.50,1.00,2.00,5.00$, and $10.00 \mathrm{mg} / \mathrm{L}$ to obtain standard curves. The concentrations of water-soluble inorganic ions in the solution were calculated using the standard curves. 


\subsection{Metallic Elements Analysis}

For the metallic element analysis, the filters were placed in a Teflon digestion tube. $10 \mathrm{~mL}$ of 1:1 $\mathrm{HNO}_{3}$ (spectral purity) was added into the tube and digested with a digestion system at a temperature of $106 \pm 0.5^{\circ} \mathrm{C}$. When the solution remained at approximately $1 \mathrm{~mL}$, another $4 \mathrm{~mL}$ of $1: 1 \mathrm{HNO}_{3}$ was added into the tubes after cooling. The digestion was then continued until there was approximately $1 \mathrm{~mL}$ solution remaining in the tube. Finally, $2 \mathrm{~mL}$ of $30 \% \mathrm{H}_{2} \mathrm{O}_{2}$ (spectral purity) was added after cooling and digestion was completed until the remaining solution was $0.50-1.0 \mathrm{~mL}$. The remaining solution was diluted with ultrapure water (specific resistance $\geq 18 \Omega \mathrm{cm}$ ) to $10.0 \mathrm{~mL}$ and then filtered through a micro-porous membrane (pore size, $0.45 \mu \mathrm{m}$; diameter, $25 \mathrm{~mm}$ ). The filtrate was stored at $4{ }^{\circ} \mathrm{C}$ until the metallic element analysis.

Metallic elements from the filtrate, including $\mathrm{Pb}, \mathrm{Mn}, \mathrm{Cu}, \mathrm{Cr}$, As, and $\mathrm{Cd}$, were analyzed by inductively coupled plasma mass spectrometry (ICP-MS, NexION300×, PerkinElmer, Waltham, MA, USA) based on the United States Environmental Protection Agency (USEPA) 3050B method. A standard solution (ICP-MS\#5183-4688) with a concentration of $10 \mathrm{mg} / \mathrm{L}$ was used. The solution was diluted with $0.1 \mathrm{M} \mathrm{HNO}_{3}$ to standard concentrations of $0.00,0.50,1.00,2.00,5.00,10.00$, and $20.00 \mu \mathrm{g} / \mathrm{L}$ to obtain the quantitative calibration curve. Then, $0.75 \mathrm{~mL}$ of filtrate of each sample was diluted to a $1.5 \mathrm{~mL}$ solution with $0.1 \mathrm{M} \mathrm{HNO}_{3}$ and the diluted filtrate was analyzed by ICP-MS to obtain the concentrations of the metallic elements in the solution.

\subsection{Data Analysis}

The water-soluble inorganic ion concentrations, measured by ICS, and metallic elements, measured by ICP-MS, were all corresponding concentrations in the filtrates. The chemical component concentrations of $\mathrm{PM}_{2.5}$ in the air were then converted as follows [28]:

$$
C_{i, a}=\left(C_{i, s}-C_{b}\right) \times \operatorname{Vol}_{s} \div\left(F_{a} \times T_{a}\right)
$$

where $C_{i, a}$ is the mass concentration of ambient water-soluble ions or elements, $\mu \mathrm{g} / \mathrm{m}^{3} ; C_{i, s}$ is the corresponding ion and element mass concentration in the solution, $\mu \mathrm{g} / \mathrm{L} ; C_{b}$ is the mass concentration of the blank filter in the solution, $\mu \mathrm{g} / \mathrm{L} ; \mathrm{Vol}_{s}$ is the volumne of the solution, $\mathrm{L} ; F_{a}$ is the flow rate of the MicroPEM, $0.0005 \mathrm{~m}^{3} / \mathrm{min}$; and $T_{a}$ is the sampling time of the filter, $\mathrm{min}$.

The relationship of indoor and outdoor $\mathrm{PM}_{2.5}$ components was studied. The indoor to outdoor (I/O) ratios of $\mathrm{PM}_{2.5}$ components were calculated as follows:

$$
I / O_{i}=\frac{C_{\text {in } i}}{C_{\text {out } i}}
$$

where $C_{\text {in } i}$ is the concentration of chemical component $i$ in indoor $\mathrm{PM}_{2.5} ; C_{\text {out } i}$ is the corresponding concentration of chemical component $i$ in outdoor $\mathrm{PM}_{2.5}$.

The indoor/outdoor correlation coefficient of $\mathrm{PM}_{2.5}$ chemical compositions was evaluated by the Spearman correlation analysis. The statistical analyses of indoor and outdoor $\mathrm{PM}_{2.5}$ concentrations and chemical components were performed using SPSS 18.0.

\subsection{Health Risk Assessment}

The health risk assessment of $\mathrm{PM}_{2.5}$-bound metallic elements by inhalational exposure pathways for adults and children was conducted based on the method provided by tUSEPA [37]:

$$
E C_{i}=\left(C A_{i} \times \mathrm{ET} \times \mathrm{EF} \times \mathrm{ED}\right) / \mathrm{AT}
$$

where $\mathrm{EC}_{i}$ is the exposure concentration of metallic element $i\left(\mathrm{ng} / \mathrm{m}^{3}\right) ; \mathrm{CA}_{i}$ is the concentration of metallic element $i$ in the air $\left(\mathrm{ng} / \mathrm{m}^{3}\right)$.; in this study, the upper bounds of the $95 \%$ confidence interval for the mean concentration of metallic elements $i\left(\mathrm{C}_{\mathrm{UCL}} i\right)$, regarded as an estimate of the "reasonable 
maximum exposure," were referred to as " $\mathrm{CA}_{i}$ " [29]; ET is the exposure time (hours/day); EF is the exposure frequency (days/year); ED is the exposure duration (24 years for adults and 6 years for children); AT is the average time, for carcinogens (AT $=$ lifetime in years $\times 365$ days/year $\times 24 \mathrm{~h} /$ day) and for noncarcinogens (AT $=\mathrm{ED}$ in years $\times 365$ days/year $\times 24 \mathrm{~h} /$ day).

The health risk assessment for metallic elements was quantified for noncarcinogenic and carcinogenic effects. The noncarcinogenic risk was evaluated by the hazard quotient (HQ), while the carcinogenic risk was evaluated by the excess cancer risk (CR) using the following equation:

$$
\begin{gathered}
\mathrm{HQ}_{\mathrm{i}}=\frac{E C_{i}}{R f C_{i}} \times 10^{-6} \\
\mathrm{HI}=\sum \mathrm{HQ}_{\mathrm{i}}
\end{gathered}
$$

where $\mathrm{HQ}_{\mathrm{i}}$ is the hazard quotient of metal elements $\mathrm{i} ; \mathrm{RfC}_{\mathrm{i}}$ is the inhalation reference concentration for the non-carcinogenic element $\mathrm{i}\left(\mathrm{mg} / \mathrm{m}^{3}\right)$; and $\mathrm{HI}$ (hazard index) is the sum of $\mathrm{HQ}$. An $\mathrm{HI} \leq 1$ indicates no significant risk of noncarcinogenic health effects, whereas an $\mathrm{HI}>1$ indicates the possibility of a noncarcinogenic health effect [37].

$$
\begin{gathered}
\mathrm{CR}_{\mathrm{i}}=E C_{i} \times I U R_{i} \times 10^{-3} \\
\mathrm{CR}=\sum \mathrm{CR}_{\mathrm{i}}
\end{gathered}
$$

where $C R_{i}$ is the cancer risk of the metal elements; $I U R_{i}$ is the inhalation unit risk for carcinogenic element $\mathrm{i}\left(\mu \mathrm{g} / \mathrm{m}^{3}\right)^{-1}$; and $\mathrm{CR}$ is the sum of $\mathrm{CR}_{\mathrm{i}}$. When the $\mathrm{CR}$ is $>10^{-4}$, it indicates a serious risk of cancer, while a CR value between $1.0 \times 10^{-4}$ and $1.0 \times 10^{-6}$ is acceptable. When $\mathrm{CR}$ is $<10^{-6}$, it indicates that the risk is minimum.

The RfC and IUR for selected metallic elements are cited from the USEPA website in the screening level (RSL) tables shown in Table 2 [38]. For the metallic element, $\mathrm{Cr}$, it is important to notice that $\mathrm{Cr}$ in the environment is usually composed of $\mathrm{Cr}^{6+}$ and $\mathrm{Cr}^{3+}$. The concentrations of $\mathrm{Cr}$ measured in this study are the total concentrations of $\mathrm{Cr}^{6+}$ and $\mathrm{Cr}^{3+} . \mathrm{Cr}^{6+}$ is classified as a human carcinogen, while $\mathrm{Cr}^{3+}$ has no carcinogenic effects. The ratio of $\mathrm{Cr}^{6+}$ to $\mathrm{Cr}^{3+}$ has been reported to be 1:6. Therefore, the concentrations of $\mathrm{Cr}^{6+}$ in this study were assumed to be $1 / 7$ of the total $\mathrm{Cr}$ to calculate the health risk $[39,40]$.

Table 2. Relative toxicity values of metallic elements used in this study.

\begin{tabular}{ccccccc}
\hline $\begin{array}{c}\text { Toxicity } \\
\text { Parameters }\end{array}$ & Pb & Mn & Cu & Cr & As & Cd \\
\hline $\left.\operatorname{IUR}\left(\mu \mathrm{g} / \mathrm{m}^{3}\right)\right)^{-1}$ & $1.2 \times 10^{-5}$ & - & - & $1.2 \times 10^{-2}$ & $4.3 \times 10^{-3}$ & $1.8 \times 10^{-3}$ \\
$\operatorname{RfC}\left(\mathrm{mg} / \mathrm{m}^{3}\right)$ & - & $5.0 \times 10^{-5}$ & - & $1.0 \times 10^{-4}$ & $1.5 \times 10^{-5}$ & $1.0 \times 10^{-5}$ \\
\hline
\end{tabular}

\section{Results and Discussion}

\subsection{Seasonal Variations of $P M_{2.5}$ and Chemical Composition}

\subsection{1. $\mathrm{PM}_{2.5}$ Concentrations}

During the sampling period, the average concentrations of $\mathrm{PM}_{2.5}$ in indoor and outdoor environments were $46.86 \pm 21.75 \mu \mathrm{g} / \mathrm{m}^{3}$ and $51.44 \pm 29.15 \mu \mathrm{g} / \mathrm{m}^{3}$, respectively. Generally, the indoor $\mathrm{PM}_{2.5}$ concentrations were lower than those from outdoors. Seasonal variability of both indoor and outdoor $\mathrm{PM}_{2.5}$ concentrations was observed in this study with the highest concentrations occurring in winter and the lowest concentrations occurring in summer. Detailed information about the seasonal variations of indoor/outdoor $\mathrm{PM}_{2.5}$ and influencing factors were discussed in our previous study [36]. 


\subsubsection{Water-Soluble Ions in $\mathrm{PM}_{2.5}$}

The mass concentrations of inorganic water-soluble ions in $\mathrm{PM}_{2.5}$ presented distinctly seasonal distribution features as shown in Figure 1. For the outdoor $\mathrm{PM}_{2.5}$, the order of the total water-soluble ion concentration $\left(\mathrm{Cl}^{-}, \mathrm{NO}_{3}{ }^{-}, \mathrm{SO}_{4}{ }^{2-}, \mathrm{Na}^{+}, \mathrm{NH}_{4}{ }^{+}, \mathrm{K}^{+}, \mathrm{Mg}^{2+}\right.$, and $\left.\mathrm{Ca}^{2+}\right)$ levels in the four seasons was winter $>$ autumn $>$ spring $>$ summer. This seasonal pattern is consistent with the seasonal distributions of outdoor $\mathrm{PM}_{2.5}$ concentrations, and that commonly observed in other cities in China [13]. The total concentrations of the ions were $23.14 \mu \mathrm{g} / \mathrm{m}^{3}, 15.87 \mu \mathrm{g} / \mathrm{m}^{3}, 28.82 \mu \mathrm{g} / \mathrm{m}^{3}$, and $33.11 \mu \mathrm{g} / \mathrm{m}^{3}$ in spring, summer, autumn, and winter, respectively. Compared with the results from other studies, the concentrations of the ions observed in this study were similar to the results from another study conducted in Nanjing [8], but much lower than in some heavily polluted cities in China, such as Tianjin [41], Jinan [25], and Beijing [32].

\section{Indoor}
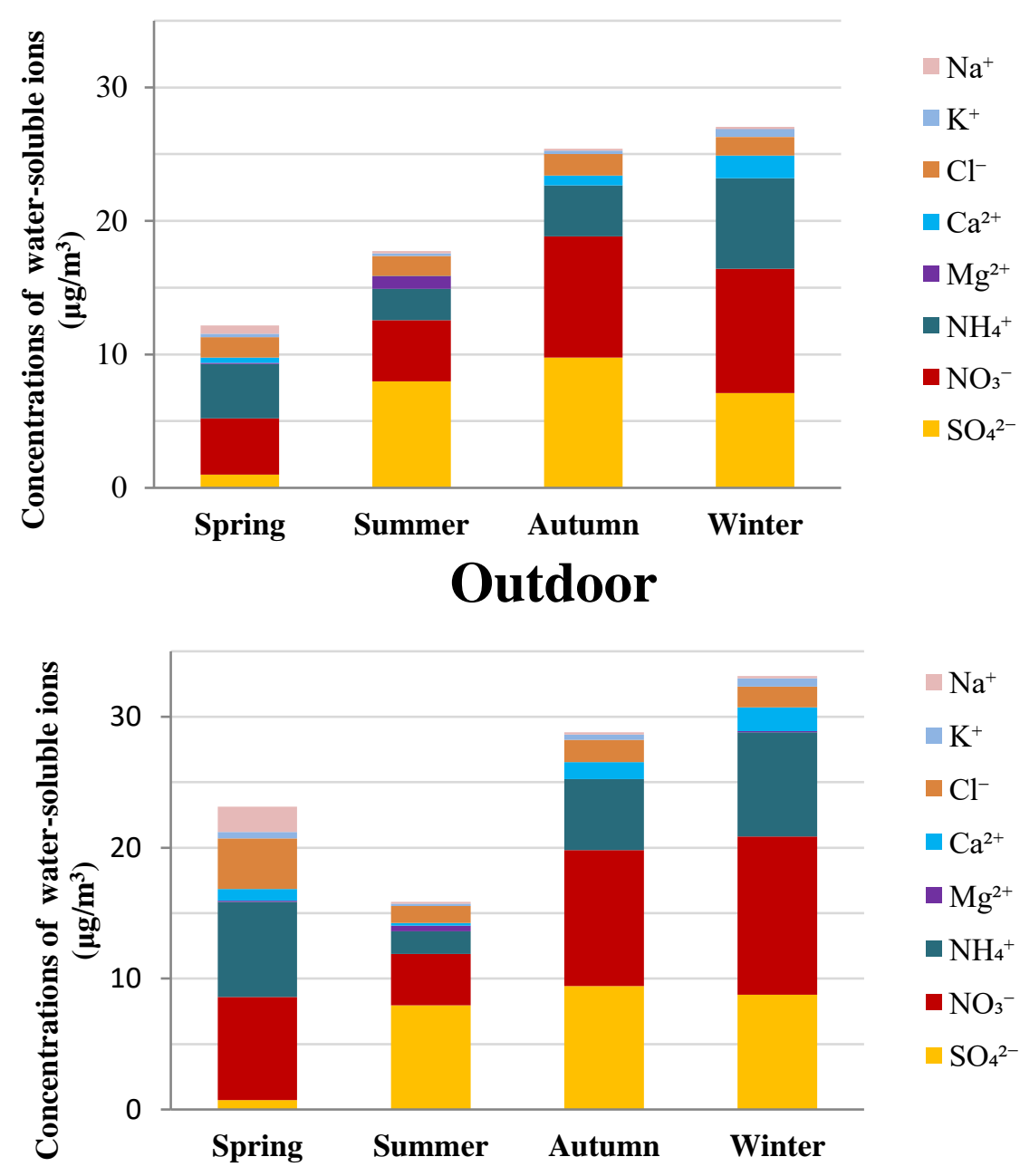

Figure 1. Seasonal variations of water-soluble ions in indoor and outdoor $\mathrm{PM}_{2.5}$.

In indoor $\mathrm{PM}_{2.5}$, the concentrations of the ions were $12.18 \mu \mathrm{g} / \mathrm{m}^{3}, 17.74 \mu \mathrm{g} / \mathrm{m}^{3}, 25.40 \mu \mathrm{g} / \mathrm{m}^{3}$, and $27.04 \mu \mathrm{g} / \mathrm{m}^{3}$ in spring, summer, autumn, and winter, respectively. Generally, the total concentration of water-soluble ions in the indoor $\mathrm{PM}_{2.5}$ was lower than that from outdoors except in summer. Different seasonal variations of the water-soluble ions in indoor $\mathrm{PM}_{2.5}$ were observed in samples from the outdoors, in the order of winter $>$ autumn $>$ summer $>$ spring (Figure 1). The highest indoor concentration of ions was observed in winter, similar to that in the outdoor $\mathrm{PM}_{2.5}$. However, the average concentration of the investigated ions in summer was higher than that in spring. In summer, windows 
were often closed while air conditioning was used due to the high temperature in Nanjing [36], which may lead to the accumulation of $\mathrm{PM}_{2.5}$ and water-soluble ions in the summer. The average concentrations of water-soluble ions in this study are either higher [42] or lower $[43,44]$ than those of other studies conducted in a single season, mainly depending on the concentration of ions in the outdoor $\mathrm{PM}_{2.5}$ and indoor activities [25,41].

Due to the differences in the sampling households in different seasons, the seasonal trends of water-soluble ions in homes sampled across the four seasons $(N=11)$ were further analyzed. For the outdoor $\mathrm{PM}_{2.5}$ samples, the average concentrations of the eight ions were $13.56 \mu \mathrm{g} / \mathrm{m}^{3}, 11.18 \mu \mathrm{g} / \mathrm{m}^{3}$, $21.19 \mu \mathrm{g} / \mathrm{m}^{3}$, and $23.54 \mu \mathrm{g} / \mathrm{m}^{3}$ in spring, summer, autumn, and winter, respectively. Whereas in indoor environments, the concentrations were $8.50 \mu \mathrm{g} / \mathrm{m}^{3}, 11.57 \mu \mathrm{g} / \mathrm{m}^{3}, 20.19 \mu \mathrm{g} / \mathrm{m}^{3}$, and $18.57 \mu \mathrm{g} / \mathrm{m}^{3}$ in spring, summer, autumn, and winter, respectively. The overall seasonal trends of water-soluble ions in the 11 homes are similar to that of the total samples (Figure 1), indicating that the differences between sampling homes across the four seasons did not affect the seasonal variations of heavy metals in indoor and outdoor $\mathrm{PM}_{2.5}$.

To better understand the difference in the water-soluble ions between the indoor and outdoor environment, the mass proportions of the water-soluble ions were calculated by dividing the mass concentrations of ions by the corresponding $\mathrm{PM}_{2.5}$ mass concentrations. For the outdoor samples, the investigated water-soluble ions accounted for approximately $18.99 \%, 59.29 \%, 46.10 \%$, and $43.67 \%$ of the outdoor $\mathrm{PM}_{2.5}$ mass in spring, summer, autumn, and winter, respectively. In the residential indoor environment, the water-soluble ions accounted for approximately $19.71 \%, 46.38 \%, 48.53 \%$, and $44.81 \%$ of the indoor $\mathrm{PM}_{2.5}$ mass in spring, summer, autumn, and winter, respectively. The highest mass proportions of water-soluble ions were observed in summer for both indoor and outdoor samples, followed by autumn, winter, and spring, which is different from the seasonal trends of the $\mathrm{PM}_{2.5}$ concentrations. The result indicated that the higher $\mathrm{PM}_{2.5}$ concentrations in winter and autumn did not increase the proportion of water-soluble ions.

Secondary inorganic aerosols $\left(\mathrm{NO}_{3}{ }^{-}, \mathrm{SO}_{4}{ }^{2-}\right.$, and $\left.\mathrm{NH}_{4}{ }^{+}\right)$were found to be the dominant constituents for both indoor and outdoor $\mathrm{PM}_{2.5}$, accounting for approximately $64.22 \%-88.07 \%$ and $78.73 \%-87.41 \%$ of the mass of water-soluble ions in indoor and outdoor $\mathrm{PM}_{2.5}$, respectively. The result is consistent with the studies conducted by Wang et al. [41] and He et al. [14]. $\mathrm{SO}_{4}{ }^{2-}, \mathrm{NO}_{3}{ }^{-}$, and $\mathrm{NH}_{4}{ }^{+}$ were formed through photochemical reactions with $\mathrm{SO}_{2}, \mathrm{NO}_{2}$, and $\mathrm{NH}_{3}[25,45]$. The contributions of sea-salt species $\left(\mathrm{Cl}^{-}\right.$and $\left.\mathrm{Na}^{+}\right)$and crustal elements $\left(\mathrm{K}^{+}, \mathrm{Ca}^{2+}, \mathrm{Mg}^{2+}\right)$ to the total water-soluble ions were observed to be much lower than the total secondary aerosols in indoor and outdoor $\mathrm{PM}_{2.5}$. Hassanvand et al. investigated the water-soluble concentrations in particles of a different size and found that sea-salt species and crustal elements were mainly found in coarse particles [42].

\subsubsection{Metallic Elements in $\mathrm{PM}_{2.5}$}

During the sampling period, the average concentrations of the total metallic elements $(\mathrm{Pb}, \mathrm{Mn}$, $\mathrm{Cu}, \mathrm{Cr}, \mathrm{As}$, and Cd) were $209.78 \pm 196.18 \mathrm{ng} / \mathrm{m}^{3}$ and $221.58 \pm 163.49 \mathrm{ng} / \mathrm{m}^{3}$ in indoor and outdoor environments, respectively. Indoor concentrations of total elements were slightly lower than those from the outdoors, indicating that indoor environments were effective at providing protection from metallic element pollution in outdoor $\mathrm{PM}_{2.5}$.

Both the indoor and outdoor mass concentrations of the metallic elements varied with the season significantly (Figure 2). The total concentration of metallic elements in outdoor environments was highest in autumn $\left(349.01 \pm 257.15 \mathrm{ng} / \mathrm{m}^{3}\right)$, followed by winter $\left(259.14 \pm 151.62 \mathrm{ng} / \mathrm{m}^{3}\right)$, summer $\left(221.96 \pm 81.07 \mathrm{ng} / \mathrm{m}^{3}\right)$, and spring $\left(100.44 \pm 64.47 \mathrm{ng} / \mathrm{m}^{3}\right)$. Whereas in indoor environments, the highest metallic elements concentrations occurred in summer $\left(287.12 \pm 301.72 \mathrm{ng} / \mathrm{m}^{3}\right)$, followed by autumn $\left(262.20 \pm 129.68 \mathrm{ng} / \mathrm{m}^{3}\right)$, winter $\left(236.05 \pm 98.81 \mathrm{ng} / \mathrm{m}^{3}\right)$, and spring $\left(72.30 \pm 41.28 \mathrm{ng} / \mathrm{m}^{3}\right)$. The seasonal trends of metallic elements' concentrations in the 11 homes that participated across the four seasons were also analyzed. The average concentrations of the metallic elements in outdoor $\mathrm{PM}_{2.5}$ were $84.92 \mathrm{ng} / \mathrm{m}^{3}, 195.44 \mathrm{ng} / \mathrm{m}^{3}, 270.49 \mathrm{ng} / \mathrm{m}^{3}$, and $229.10 \mathrm{ng} / \mathrm{m}^{3}$ in spring, summer, autumn, 
and winter, respectively. For indoor $\mathrm{PM}_{2.5}$ samples, the mean concentrations of the investigated metallic elements were $77.52 \mathrm{ng} / \mathrm{m}^{3}$ in spring, $221.65 \mathrm{ng} / \mathrm{m}^{3}$ in summer, $211.79 \mathrm{ng} / \mathrm{m}^{3}$ in autumn, and $201.52 \mathrm{ng} / \mathrm{m}^{3}$ in winter, respectively. The seasonal variations in indoor and outdoor $\mathrm{PM}_{2.5}$ samples in the 11 homes was consistent with the trends of the total samples, indicating that the difference of sampling homes across the four seasons did not affect the seasonal variations of metallic elements in indoor and outdoor $\mathrm{PM}_{2.5}$. The seasonal variations of indoor and outdoor $\mathrm{PM}_{2.5}$ concentrations was discussed in our previous study, with the highest concentrations occurring in winter and the lowest occurring in summer [36]. In this study, indoor and outdoor metallic elements exhibited a different seasonal trend from that of $\mathrm{PM}_{2.5}$ mass concentrations. Although the highest $\mathrm{PM}_{2.5}$ concentrations in winter were observed in the outdoor samples, the highest total metallic element concentrations were observed in autumn. In summer, $\mathrm{PM}_{2.5}$ concentrations were lowest in indoor environments. However, the metallic element concentration was observed to be the highest. The results indicated that the lower concentrations of $\mathrm{PM}_{2.5}$ may not result in the lower concentrations of metallic elements. In addition to the seasonal variations of $\mathrm{PM}_{2.5}$ concentrations, more attention should be paid to its chemical composition, such as the metallic elements, which are harmful to humans.

\section{Indoor}

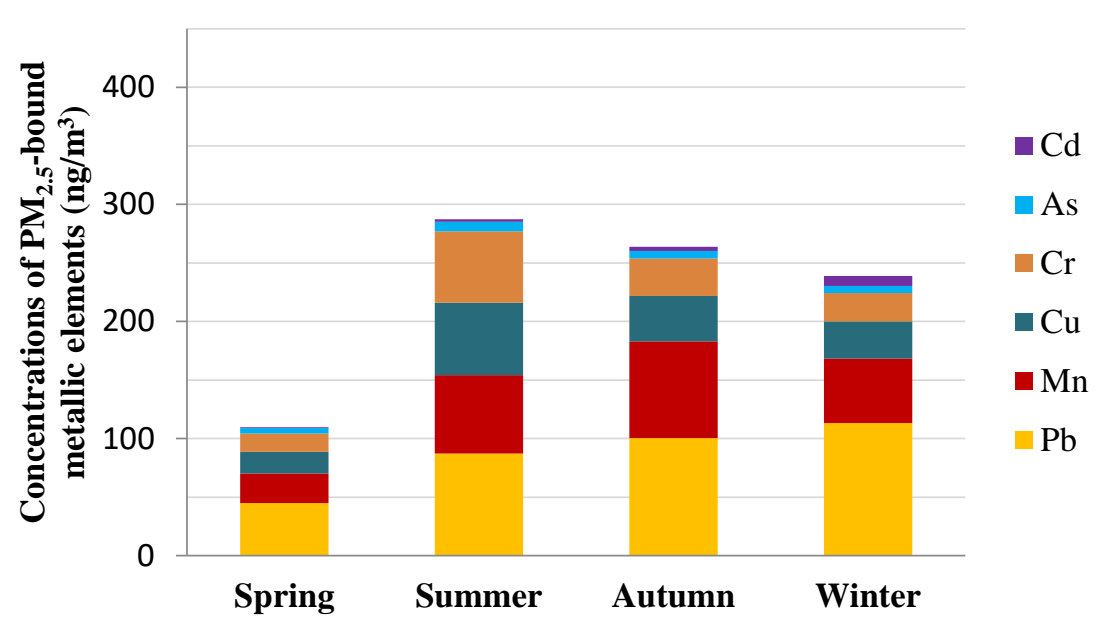

\section{Outdoor}

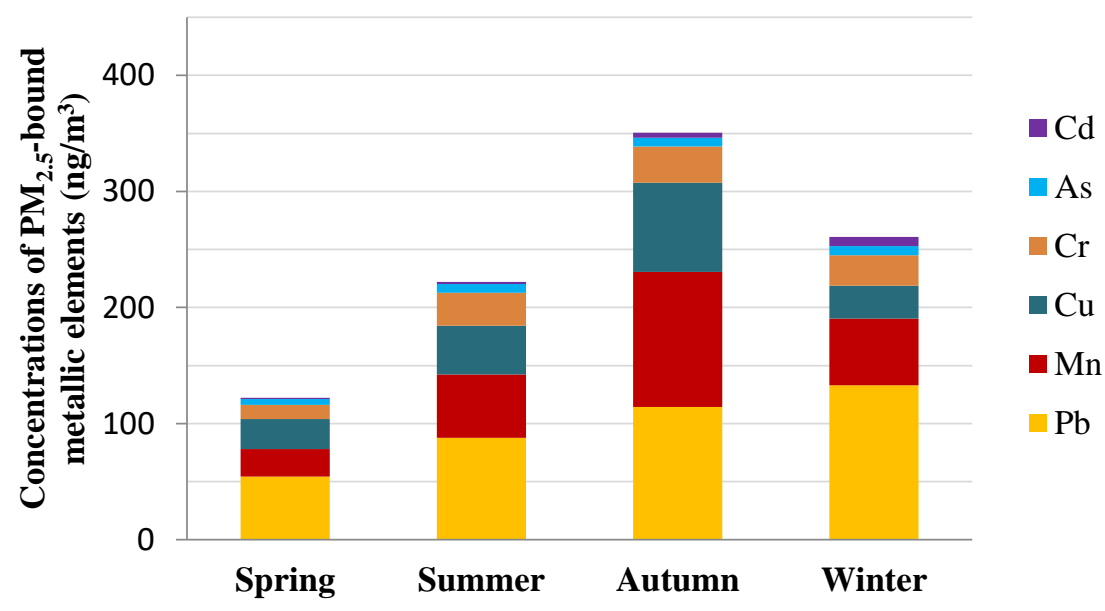

Figure 2. Seasonal variations of metallic elements in indoor and outdoor $\mathrm{PM}_{2.5}$. 
The mass proportions of the metallic elements in indoor and outdoor $\mathrm{PM}_{2.5}$ were also calculated by dividing the mass concentrations of the investigated elements by the corresponding $\mathrm{PM}_{2.5}$ mass concentrations. Metallic elements accounted for approximately $0.18 \%, 0.97 \%, 0.78 \%$, and $0.51 \%$ of the outdoor $\mathrm{PM}_{2.5}$ samples in spring, summer, autumn, and winter, respectively. For indoor samples, the investigated elements accounted for $0.15 \%, 0.94 \%, 0.59 \%$, and $0.54 \%$ of the indoor $\mathrm{PM}_{2.5}$ mass in spring, summer, autumn, and winter, respectively. The seasonal variation of the mass proportions of the metallic elements was consistent with that of the water-soluble ions. However, the mass proportions of metallic elements in $\mathrm{PM}_{2.5}$ were significantly lower than the ions. Moreover, the mass proportions of elements in indoor $\mathrm{PM}_{2.5}$ were slightly lower than that of the outdoor $\mathrm{PM}_{2.5}$. Indoor $\mathrm{PM}_{2.5}$ comes from both indoor and outdoor sources, and the lower proportions of metallic elements in indoor $\mathrm{PM}_{2.5}$ indicate that the content of metallic elements in $\mathrm{PM}_{2.5}$ generated by indoor sources may be lower than that of the outdoor sources.

Of the individual metals, the mass concentrations of the metallic elements in indoor $\mathrm{PM}_{2.5}$ decreases in the order as follows: $\mathrm{Pb}>\mathrm{Mn}>\mathrm{Cu}>\mathrm{Cr}>\mathrm{As}>\mathrm{Cd}$ in spring; $\mathrm{Pb}>\mathrm{Mn}>\mathrm{Cu}>\mathrm{Cr}>\mathrm{As}>$ $\mathrm{Cd}$ in summer; $\mathrm{Pb}>\mathrm{Mn}>\mathrm{Cu}>\mathrm{Cr}>\mathrm{As}>\mathrm{Cd}$ in autumn; and $\mathrm{Pb}>\mathrm{Mn}>\mathrm{Cu}>\mathrm{Cr}>\mathrm{Cd}>\mathrm{As}$ in winter. Similar orders of elements were also found in the outdoor $\mathrm{PM}_{2.5}$, in the order of $\mathrm{Pb}>\mathrm{Cu}>\mathrm{Mn}>\mathrm{Cr}>\mathrm{As}$ $>\mathrm{Cd}$ in spring; $\mathrm{Pb}>\mathrm{Mn}>\mathrm{Cu}>\mathrm{Cr}>\mathrm{As}>\mathrm{Cd}$ in summer; $\mathrm{Pb}>\mathrm{Mn}>\mathrm{Cu}>\mathrm{Cr}>\mathrm{As}>\mathrm{Cd}$ in autumn; and $\mathrm{Pb}>\mathrm{Mn}>\mathrm{Cu}>\mathrm{Cr}>\mathrm{Cd}>\mathrm{As}$ in winter. $\mathrm{Pb}, \mathrm{Mn}$, and $\mathrm{Cu}$ were the dominant components of the metallic elements in the indoor $\mathrm{PM}_{2.5}$ in the four seasons, accounting for approximately $81.53 \%-89.95 \%$ of the total metallic elements in the $\mathrm{PM}_{2.5}$, which is consistent with that from the outdoors $(82.76 \%-90.60 \%)$. Specially, $\mathrm{Pb}$ was the most abundant element and the only element that exhibited lower concentrations in indoor samples than outdoor samples over the four seasons, indicating that outdoor sources were the main contributor to indoor $\mathrm{Pb}$ in $\mathrm{PM}_{2.5}$. The pollution of particle-associated $\mathrm{Pb}$ is widespread in China due to the use of leaded gasoline, although it has been prohibited since 2000 [15]. Pb concentration in the troposphere has decreased as a consequence of the phasing-out of leaded gasoline, but $\mathrm{Pb}$ remains essentially affected by anthropogenic sources in atmospheric aerosols [46]. Motor vehicle exhaust was considered to be the main source of $\mathrm{Pb}$ emissions [47]. The highest concentrations of $\mathrm{Pb}$ in indoor and outdoor $\mathrm{PM}_{2.5}$ samples were also found by Bi et al. in Nanjing [28]. As and Cd were found to have the lowest concentrations in this study. As and $\mathrm{Cd}$ are indicators of particulate matter from coal burning [33]. Zhang et al. found that significant higher concentrations of As and $\mathrm{Cd}$ were in seasons where heating was used compared to seasons without heating use [26]. The concentrations of As and $\mathrm{Cd}$ were low in this study, indicating a lower influence of coal burning sources on $\mathrm{PM}_{2.5}$ samples.

\subsection{Relationship of Indoor and Outdoor $P M_{2.5}$ Chemical Composition}

\subsubsection{Water-Soluble Ions}

The I/O ratios and indoor-outdoor Spearman correlation coefficients (r) for water-soluble ions in $\mathrm{PM}_{2.5}$ were calculated and are presented in Table 3.

Table 3. The indoor-outdoor relationship of water-soluble ions in $\mathrm{PM}_{2.5}$.

\begin{tabular}{|c|c|c|c|c|c|c|c|c|}
\hline \multirow{2}{*}{ Ion } & \multicolumn{2}{|c|}{ Spring } & \multicolumn{2}{|c|}{ Summer } & \multicolumn{2}{|c|}{ Autumn } & \multicolumn{2}{|c|}{ Winter } \\
\hline & $\mathrm{I} / \mathrm{O}$ & $r$ & I/O & $r$ & I/O & $r$ & $\mathrm{I} / \mathrm{O}$ & $r$ \\
\hline $\mathrm{Cl}^{-}$ & $0.96 \pm 1.04$ & $0.88^{b}$ & $1.19 \pm 0.57$ & $0.60^{b}$ & $0.94 \pm 0.18$ & $0.68^{a}$ & $0.89 \pm 0.22$ & $0.46^{a}$ \\
\hline $\mathrm{NO}_{3}{ }^{-}$ & $0.72 \pm 0.51$ & $0.69^{b}$ & $1.29 \pm 0.57$ & $0.61^{b}$ & $0.92 \pm 0.35$ & $0.68^{a}$ & $0.89 \pm 0.50$ & $0.62^{b}$ \\
\hline $\mathrm{SO}_{4}^{2-}$ & $0.98 \pm 0.15$ & $0.71^{b}$ & $1.12 \pm 0.66$ & $0.60^{b}$ & $0.99 \pm 0.32$ & $0.66^{a}$ & $0.90 \pm 0.39$ & $0.61^{a}$ \\
\hline $\mathrm{Na}^{+}$ & $1.27 \pm 1.29$ & $0.80^{b}$ & $1.26 \pm 0.91$ & $0.50^{\mathrm{a}}$ & $0.64 \pm 0.51$ & 0.22 & $4.67 \pm 8.55$ & 0.04 \\
\hline $\mathrm{NH}_{4}^{+}$ & $0.66 \pm 0.35$ & $0.84^{b}$ & $3.05 \pm 5.06$ & $0.93^{b}$ & $0.55 \pm 0.40$ & $0.91^{b}$ & $1.45 \pm 2.49$ & $0.63^{b}$ \\
\hline $\mathrm{K}^{+}$ & $0.90 \pm 0.97$ & $0.65^{b}$ & $1.73 \pm 2.64$ & $0.56^{\mathrm{a}}$ & $0.74 \pm 0.38$ & $0.89^{b}$ & $1.40 \pm 1.94$ & 0.09 \\
\hline $\mathrm{Mg}^{2+}$ & $0.87 \pm 0.66$ & $0.51^{a}$ & - & 0.06 & - & - & - & - \\
\hline $\mathrm{Ca}^{2+}$ & $1.85 \pm 2.02$ & 0.27 & - & 0.07 & $0.63 \pm 0.40$ & $0.80^{c}$ & $1.29 \pm 1.29$ & 0.02 \\
\hline
\end{tabular}


The I/O ratio is an indicator for evaluating the difference between indoor concentrations and the corresponding outdoor levels or for evaluating the strength of indoor/outdoor sources [48]. In this study, higher I/O ratios of water-soluble ions in summer and winter were found, while the I/O ratios in spring and autumn were much lower. The results suggested that there were different sources for water-soluble ions in different seasons. In hot summers and cold winters, windows were often closed by occupants while air conditioners were used [36], which may reduce indoor ventilation and result in the accumulation of indoor water-soluble ions. In spring and autumn, most of the I/O ratios of ions were less than 1 , suggesting that the indoor ions were generated by outdoor sources. The temperature is favorable in spring and autumn and the windows were often opened for ventilation, which can increase the indoor air-exchange rate and outdoor air pollution infiltration [48].

The correlation between indoor and outdoor ions in $\mathrm{PM}_{2.5}$ in different seasons is shown in Table 3. Results showed that most of the indoor and outdoor water-soluble ions in $\mathrm{PM}_{2.5}$ were significantly correlated $(p<0.1)$ except $\mathrm{Mg}^{2+}$ and $\mathrm{Ca}^{2+}$. Crustal elements $\left(\mathrm{Mg}^{2+}\right.$ and $\left.\mathrm{Ca}^{2+}\right)$ mainly come from outdoor sources, such as dust from soil, road surfaces, and construction, and they often exist in coarse particles, such as $\mathrm{PM}_{10}$ [42]. Moreover, the lower detection rate of the two cations (indoor $\mathrm{Mg}^{2+}$ : $14.41 \%$; $\mathrm{Ca}^{2+}: 55.08 \%$ vs. outdoor $\mathrm{Mg}^{2+}: 15.25 \%$; $\mathrm{Ca}^{2+}: 60.17 \%$ ) in this study may also lead to the lack of an indoor-outdoor correlation for the two ions. The correlation coefficients (r) between indoor and outdoor ions were observed to be higher in transitional seasons (spring and autumn) than in summer and winter due to the long duration of ventilation in transition seasons. The result is consistent with the results of the I/O ratios of the ions.

\subsubsection{Metallic Elements}

The indoor to outdoor $(\mathrm{I} / \mathrm{O})$ ratios and indoor-outdoor Spearman correlation coefficients for metallic elements in $\mathrm{PM}_{2.5}$ are presented in Table 4.

Table 4. The indoor-outdoor relationship of metallic metals in $\mathrm{PM}_{2.5}$.

\begin{tabular}{|c|c|c|c|c|c|c|c|c|}
\hline \multirow{2}{*}{ Element } & \multicolumn{2}{|c|}{ Spring } & \multicolumn{2}{|c|}{ Summer } & \multicolumn{2}{|c|}{ Autumn } & \multicolumn{2}{|c|}{ Winter } \\
\hline & $\mathrm{I} / \mathrm{O}$ & $\mathbf{r}$ & $\mathrm{I} / \mathrm{O}$ & $\mathbf{r}$ & I/O & $\mathbf{r}$ & I/O & $\mathbf{r}$ \\
\hline $\mathrm{Pb}$ & $0.90 \pm 0.35$ & $0.62^{c}$ & $1.07 \pm 0.33$ & $0.50^{b}$ & $0.92 \pm 0.41$ & 0.44 & $1.01 \pm 0.50$ & $0.58^{c}$ \\
\hline $\mathrm{Mn}$ & $0.55 \pm 0.35$ & $0.40^{\mathrm{a}}$ & $1.26 \pm 0.87$ & $0.39^{\mathrm{a}}$ & $0.84 \pm 0.37$ & $0.61^{b}$ & $1.34 \pm 1.67$ & $0.43^{b}$ \\
\hline $\mathrm{Cu}$ & $0.80 \pm 0.55$ & $0.62^{c}$ & $2.37 \pm 5.43$ & 0.28 & $0.86 \pm 0.64$ & 0.00 & $7.92 \pm 23.37$ & 0.21 \\
\hline $\mathrm{Cr}$ & $0.89 \pm 0.43$ & 0.20 & $2.65 \pm 7.89$ & 0.02 & $1.49 \pm 1.02$ & $0.49^{a}$ & $1.18 \pm 0.82$ & 0.08 \\
\hline As & $0.88 \pm 0.48$ & $0.78^{c}$ & $1.21 \pm 0.55$ & $0.82^{c}$ & $0.96 \pm 0.55$ & 0.42 & $1.01 \pm 0.58$ & $0.64^{c}$ \\
\hline $\mathrm{Cd}$ & $1.02 \pm 0.62$ & $0.65^{c}$ & $1.50 \pm 1.14$ & $0.57^{c}$ & $1.50 \pm 1.64$ & $0.66^{c}$ & $2.09 \pm 3.01$ & $0.50^{b}$ \\
\hline
\end{tabular}

The I/O ratios in summer and winter are above 1 for all elements. In spring and autumn, relatively lower I/O ratios for most of the elements were observed. The seasonal variations of I/O ratios for metallic elements are consistent with that of the water-soluble ions in $\mathrm{PM}_{2.5}$ discussed in Section 3.2.1. The difference in indoor ventilation may be the main reason for the seasonal variations of the elements' $\mathrm{I} / \mathrm{O}$ ratios. Some individual elements exhibited a different seasonal pattern from the others, such as $\mathrm{Cr}$ and $\mathrm{Cd}$. For the elements, $\mathrm{Cr}$ and $\mathrm{Cd}$, higher I/O ratios can still be found in spring and autumn than those of other elements, suggesting that there may be indoor sources for the two elements. $\mathrm{Cr}$ and $\mathrm{Cd}$ are mainly derived from indoor sources, such as cigarette smoke, cosmetics, and paint chips [27,49]; this results in higher I/O ratios for these two elements.

The results of the Spearman correlation analysis showed that $\mathrm{Pb}, \mathrm{Mn}, \mathrm{As}$, and $\mathrm{Cd}$ in the indoor and outdoor $\mathrm{PM}_{2.5}$ were significantly correlated in most seasons $(p<0.05)$. The results indicated that outdoor concentrations were the main factors determining the indoor concentrations of $\mathrm{Pb}, \mathrm{Mn}$, $\mathrm{As}$, and $\mathrm{Cd}$. Indoor $\mathrm{Cu}$ and $\mathrm{Cr}$ concentrations were only observed to be correlated with those of the 
outdoors in transitional seasons ( $\mathrm{Cu}$ in spring and $\mathrm{Cr}$ in autumn), suggesting the main contributions of indoor sources for $\mathrm{Cu}$ and $\mathrm{Cr}$.

\subsection{Health Risk Assessment of Metallic Elements}

Toxic metallic elements in $\mathrm{PM}_{2.5}$ have potential effects on human health through inhalation, dermal contact, and ingestion into human bodies [50], especially for children who are more sensitive to these metals than adults due to their still developing immune system and lungs [51], their age, lower body weight, and lower tolerance to toxins [52]. In this study, a health risk assessment of metallic elements in $\mathrm{PM}_{2.5}$ through inhalation pathways was conducted for both adults and children.

The carcinogenic risks for metallic elements from indoor and outdoor $\mathrm{PM}_{2.5}$ are shown in Table 5. The risk levels of carcinogenic metals for indoor and outdoor $\mathrm{PM}_{2.5}$ were all within the acceptable levels (between $1.0 \times 10^{-4}$ and $1.0 \times 10^{-6}$ ), and the risk of metals decreased in the following order: $\mathrm{Cr}>\mathrm{As}>\mathrm{Cd}>\mathrm{Pb}$. The higher concentration of $\mathrm{PM}_{2.5}$-bound $\mathrm{Pb}$ did not result in a greater carcinogenic risk due to the lower inhalation unit risk for $\mathrm{Pb}$ shown in Table 2. $\mathrm{Cr}$ and As were found to be the two highest cancer-risk carcinogenic elements in $\mathrm{PM}_{2.5}$. The research from Wang et al. [31] in Nanjing also revealed that $\mathrm{As}$ and $\mathrm{Cr}$ in residential and ambient environments represented the highest cancer-risk to people. Similar results can be found in Tianjin and Lanzhou, China, which indicated that $\mathrm{Cr}$ and As posed the highest carcinogenic risk [26,53]. The cancer risk of the metallic metals in the outdoor $\mathrm{PM}_{2.5}$ was observed to be higher than that in the indoor $\mathrm{PM}_{2.5}$ except for $\mathrm{Cr}$, which exhibited a higher risk in indoor environments than outdoors. $\mathrm{Cr}$ is mainly derived from cigarette smoke, cosmetics, and paint chips [49]. In this study, indoor smoking activities may be the cause of higher indoor $\mathrm{Cr}$ concentrations and cancer risk [36]. Moreover, the investigated metallic elements posed a higher cancer risk to adults than children. The total cancer risk of metallic elements was higher than $10^{-6}$, but lower than $10^{-4}$, indicating that the cancer risk caused by metallic elements in indoor and outdoor $\mathrm{PM}_{2.5}$ in this study was acceptable.

Table 5. Carcinogenic and noncarcinogenic risks for metallic elements in indoor and outdoor $\mathrm{PM}_{2.5}$.

\begin{tabular}{ccccccccc}
\hline \multirow{2}{*}{$\begin{array}{c}\text { Metallic } \\
\text { Elements }\end{array}$} & \multicolumn{4}{c}{ Indoor } & \multicolumn{4}{c}{ Outdoor } \\
\cline { 2 - 9 } & Noncarcinogenic Risk (HQ) & \multicolumn{1}{c}{ Carcinogenic Risk (CR) } & Noncarcinogenic Risk (HQ) & Carcinogenic Risk (CR) \\
\cline { 2 - 10 } & Adult & Children & Adult & Children & Adult & Children & Adult & Children \\
\hline $\mathrm{Pb}$ & - & - & $2.58 \times 10^{-6}$ & $6.44 \times 10^{-7}$ & - & - & $2.94 \times 10^{-6}$ & $7.35 \times 10^{-7}$ \\
$\mathrm{Mn}$ & 1.15 & 1.15 & - & - & 1.30 & 1.30 & - & - \\
$\mathrm{Cr}$ & $4.80 \times 10^{-1}$ & $4.80 \times 10^{-1}$ & $2.82 \times 10^{-5}$ & $7.06 \times 10^{-6}$ & $2.58 \times 10^{-1}$ & $2.58 \times 10^{-1}$ & $1.51 \times 10^{-5}$ & $3.79 \times 10^{-6}$ \\
$\mathrm{As}$ & $4.69 \times 10^{-1}$ & $4.69 \times 10^{-1}$ & $1.04 \times 10^{-5}$ & $2.59 \times 10^{-6}$ & $5.31 \times 10^{-1}$ & $5.31 \times 10^{-1}$ & $1.18 \times 10^{-5}$ & $2.94 \times 10^{-6}$ \\
$\mathrm{Cd}$ & $4.64 \times 10^{-1}$ & $4.64 \times 10^{-1}$ & $2.86 \times 10^{-6}$ & $7.16 \times 10^{-7}$ & $4.89 \times 10^{-1}$ & $4.89 \times 10^{-1}$ & $3.02 \times 10^{-6}$ & $7.54 \times 10^{-7}$ \\
Total & 2.08 & 2.08 & $4.40 \times 10^{-5}$ & $1.10 \times 10^{-5}$ & 2.58 & 2.58 & $3.29 \times 10^{-5}$ & $8.22 \times 10^{-6}$ \\
\hline
\end{tabular}

The noncarcinogenic risk described in HQ for metallic elements is shown in Table 5. The HQ values of the four metallic elements occurred in the following order: $\mathrm{Mn}>\mathrm{Cr}>\mathrm{As}>\mathrm{Cd}$ (indoor) and $\mathrm{Mn}>\mathrm{As}>\mathrm{Cd}>\mathrm{Cr}$ (outdoor). For the indoor and outdoor samples, the HQ values of Mn were higher than the acceptable level of 1.0, while the $\mathrm{HQ}$ values of $\mathrm{Cr}$, As, and $\mathrm{Cd}$ were all lower than 1 . Our results indicate that $\mathrm{Cr}$, As, and $\mathrm{Cd}$ in $\mathrm{PM}_{2.5}$ would not result in noncarcinogenic health effects while Mn may cause adverse health effects. The higher noncarcinogenic risk of Mn was also found in other studies [26,53]. The HQ value of Mn in indoor environments was higher than the results conducted by Wang et al. in Nanjing, in which Mn also exhibited the highest noncarcinogenic risk over the other heavy metals [31]. Mn is used in unleaded gasoline as an anti-knocking agent and can also be used as an additive in petroleum products [54]. Moreover, $\mathrm{Mn}$ in $\mathrm{PM}_{2.5}$ had significant natural source characteristics and may be derived from soil dust [31]. As shown in Table 1, the sampling homes in this study were mostly near the roadside, so the indoor and outdoor air may be polluted by exhaust from vehicles and soil dust, resulting in the higher HQ values of Mn. According to Equation (2), the exposure concentration of metals in $\mathrm{PM}_{2.5}$ is equal to the contaminant concentration in the air for the noncarcinogenic risk assessment, thus there were no differences in the calculated 
noncarcinogenic risk between adults and children in this study. Although the HQ value of most individual metallic elements was below 1, except for $\mathrm{Mn}$, the total noncarcinogenic risk $\mathrm{HI}$ value was higher than 1 . The results suggested that the accumulative risk of exposure by inhalation to noncarcinogenic $\mathrm{PM}_{2.5}$-bound metallic elements was important to the health risk assessment. The $\mathrm{HI}$ value of all metallic elements was more than two times higher than safe levels, indicating that the total metallic elements in $\mathrm{PM}_{2.5}$ can cause potential adverse health effects for residents. Therefore, more attention should be paid to inhalation exposure of $\mathrm{PM}_{2.5}$ with toxic metallic elements.

\section{Conclusions}

This study investigated the concentrations of chemical components in indoor and outdoor $\mathrm{PM}_{2.5}$ in residences in Nanjing, China. Different seasonal variations were observed for water-soluble ions and metallic elements in indoor and outdoor $\mathrm{PM}_{2.5}$. The highest water-soluble ions in outdoor $\mathrm{PM}_{2.5}$ samples occurred in winter, and the lowest occurred in summer, which is consistent with the seasonal variations of outdoor $\mathrm{PM}_{2.5}$ concentrations. Water-soluble ions in indoor $\mathrm{PM}_{2.5}$ samples varied with the outdoor levels, except in summer, when higher concentrations of ions in indoor environments were observed compared to the outdoors. When indoor ventilation was lacking, especially in cold winters and hot summers, higher I/O ratios and lower indoor-outdoor correlations of water-soluble ions in $\mathrm{PM}_{2.5}$ were observed, suggesting the influence of indoor sources in the two seasons. Secondary inorganic aerosols $\left(\mathrm{NO}_{3}{ }^{-}, \mathrm{SO}_{4}{ }^{2-}\right.$, and $\left.\mathrm{NH}_{4}{ }^{+}\right)$were the dominant constituents of water-soluble ions in both indoor and outdoor $\mathrm{PM}_{2.5}$, which also exhibited higher indoor-outdoor correlations than other ions; this indicates that indoor secondary inorganic aerosols mainly come from the outdoors.

The metallic elements in indoor $\mathrm{PM}_{2.5}$ exhibited different seasonal variations compared to the outdoors. The highest concentrations in indoor $\mathrm{PM}_{2.5}$ were found in summer, followed by autumn, winter, and spring; for the outdoor samples, the highest concentrations occurred in autumn, followed by winter, summer, and spring. The difference in seasonal variations of metallic elements between indoor and outdoor $\mathrm{PM}_{2.5}$ indicated that even when the outdoor concentrations of metallic elements was low, people may also be exposed to higher concentrations of elements due to the accumulation of air pollutants in indoor environments. To reduce the exposure to metallic elements indoors, people should consider both indoor and outdoor sources comprehensively. The I/O ratios of metallic elements were higher than that of water-soluble ions, and the correlation coefficients were much lower. The results indicated that there may be different sources for indoor water-soluble ions and metallic elements. Further research should be conducted to investigate the source apportionment of indoor chemical compositions and provide more suggestions for improving indoor air quality and reducing human exposure and health impacts.

The health risk of metallic elements in indoor and outdoor $\mathrm{PM}_{2.5}$ was calculated in this study. A lower health risk for indoor metallic elements than the outdoors was observed except for $\mathrm{Cr}$, suggesting that there is a significant influence of indoor sources for $\mathrm{Cr}$ in indoor environments. The metallic elements posed a higher health risk to adults than children. The risk levels of carcinogenic metals for indoor and outdoor $\mathrm{PM}_{2.5}$ were all within the acceptable levels. The non-carcinogenic risks of most of the elements were within the safe limits. Mn was found to have a non-carcinogenic risk to residents in Nanjing, and the exhaust from vehicles and soil dust may be the potential sources of $\mathrm{Mn}$ in indoor and outdoor $\mathrm{PM}_{2.5}$. More attention should be paid to the pollution of $\mathrm{Mn}$ in $\mathrm{PM}_{2.5}$ in Nanjing to reduce its health impacts on residents. Moreover, a cumulative effect of noncarcinogenic risk for the elements was found to be more than two times higher than the safe levels, indicating that more attention should be paid to the inhalation exposure of $\mathrm{PM}_{2.5}$ with toxic metallic elements.

Author Contributions: Conceptualization, M.Z., S.Z. and B.J.; Data curation, C.G., S.Z.; Formal analysis, C.G., S.Z.; Supervision, B.J., M.Z. and W.J.; Writing—original draft, S.Z.; Writing—review \& editing, C.G., B.J. and M.Z.

Acknowledgments: This work was supported by the National Natural Science Foundation of China (41601546 \& 71433007) and Jiangsu Natural Science Foundation of China (BK20160624).

Conflicts of Interest: The authors declare no conflict of interest. 


\section{References}

1. Ministry of Ecology and Environment of the People's Republic of China. Ecological Environment Status Bulletin in China; Ministry of Ecology and Environment of the People's Republic of China: Beijing, China, 2018.

2. Forouzanfar, M.H.; Afshin, A.; Alexander, L.T.; Anderson, H.R.; Bhutta, Z.A.; Biryukov, S.; Brauer, M.; Burnett, R.; Cercy, K.; Charlson, F.J.; et al. Global, regional, and national comparative risk assessment of 79 behavioural, environmental and occupational, and metabolic risks or clusters of risks, 1990-2015: A systematic analysis for the Global Burden of Disease Study 2015. Lancet 2016, 388, 1659-1724. [CrossRef]

3. Brunekreef, B.; Holgate, S.T. Air pollution and health. Lancet 2002, 360, 1233-1242. [CrossRef]

4. Arnold, C. Disease burdens associated with $\mathrm{PM}_{2.5}$ exposure: How a new model provided global estimates. Environ. Health Perspect. 2014, 122, A111. [CrossRef]

5. Lin, H.; Liu, T.; Xiao, J.; Zeng, W.; Li, X.; Guo, L.; Xu, Y.; Zhang, Y.; Vaughn, M.G.; Nelson, E.J.; et al. Quantifying short-term and long-term health benefits of attaining ambient fine particulate pollution standards in Guangzhou, China. Atmos. Environ. 2016, 137, 38-44. [CrossRef]

6. Fang, D.; Wang, Q.G.; Li, H.; Yu, Y.; Lu, Y.; Qian, X. Mortality effects assessment of ambient PM 2.5 pollution in the 74 leading cities of China. Sci. Total Environ. 2016, 569, 1545-1552. [CrossRef]

7. Atkinson, R.W.; Mills, I.C.; Walton, H.A.; Anderson, H.R. Fine particle components and health-a systematic review and meta-analysis of epidemiological time series studies of daily mortality and hospital admissions. J. Expo. Sci. Environ. Epidemiol. 2015, 25, 208-214. [CrossRef] [PubMed]

8. Wang, G.H.; Wang, H.; Yu, Y.J.; Gao, S.X.; Feng, J.F.; Gao, S.T.; Wang, L.S. Chemical characterization of water-soluble components of $\mathrm{PM}_{10}$ and $\mathrm{PM}_{2.5}$ atmospheric aerosols in five locations of Nanjing, China. Atmos. Environ. 2003, 37, 2893-2902. [CrossRef]

9. Anderson, J.O.; Thundiyil, J.G.; Stolbach, A. Clearing the air: A review of the effects of particulate matter air pollution on human health. J. Med Toxicol. Off. J. Am. Coll. Med. Toxicol. 2012, 8, 166-175. [CrossRef] [PubMed]

10. Fang, G.-C.; Huang, Y.-L.; Huang, J.-H. Study of atmospheric metallic elements pollution in Asia during 2000-2007. J. Hazard. Mater. 2010, 180, 115-121. [CrossRef]

11. Zheng, G.; Xu, X.; Li, B.; Wu, K.; Yekeen, T.A.; Huo, X. Association between lung function in school children and exposure to three transition metals from an e-waste recycling area. J. Expo. Sci. Environ. Epidemiol. 2013, 23, 67-72. [CrossRef] [PubMed]

12. Liang, Z.; Zhao, X.; Chen, J.; Gao, L.; Zhu, A.; Wang, Z.; Li, S.; Shan, J.; Long, Y.; Yan, C.; et al. Seasonal characteristics of chemical compositions and sources identification of $\mathrm{PM}_{2.5}$ in Zhuhai, China. Environ. Geochem. Health 2018. [CrossRef]

13. Wang, H.; Zhu, B.; Shen, L.; Xu, H.; An, J.; Xue, G.; Cao, J. Water-soluble ions in atmospheric aerosols measured in five sites in the Yangtze River Delta, China: Size-fractionated, seasonal variations and sources. Atmos. Environ. 2015, 123, 370-379. [CrossRef]

14. He, Q.; Yan, Y.; Guo, L.; Zhang, Y.; Zhang, G.; Wang, X. Characterization and source analysis of water-soluble inorganic ionic species in $\mathrm{PM}_{2.5}$ in Taiyuan city, China. Atmos. Res. 2017, 184, 48-55. [CrossRef]

15. Zhang, J.; Zhou, X.; Wang, Z.; Yang, L.; Wang, J.; Wang, W. Trace elements in $\mathrm{PM}_{2.5}$ in Shandong Province: Source identification and health risk assessment. Sci. Total Environ. 2018, 621, 558-577. [CrossRef] [PubMed]

16. Wang, X.; He, S.; Chen, S.; Zhang, Y.; Wang, A.; Luo, J.; Ye, X.; Mo, Z.; Wu, L.; Xu, P.; et al. Spatiotemporal Characteristics and Health Risk Assessment of Heavy Metals in $\mathrm{PM}_{2.5}$ in Zhejiang Province. Int. J. Environ. Res. Public Health 2018, 15, 583. [CrossRef]

17. Atkinson, R.W.; Carey, I.M.; Kent, A.J.; van Staa, T.P.; Anderson, H.R.; Cook, D.G. Long-term exposure to outdoor air pollution and incidence of cardiovascular diseases. Epidemiology 2013, 24, 44-53. [CrossRef]

18. EPA. Exposure Factors Handbook; EPA/600/R-090/52F; Office of Research and Development: Washington, DC, USA, 2011.

19. Jang, J.Y.; Jo, S.N.; Kim, S.J.; Cheong, H.K. Development of Korean Exposure Factors Handbook. Epidemiology 2008, 19, S214. [CrossRef] [PubMed]

20. Duan, X. Exposure Factors Handbook of Chinese Population (Adults); China Environmental Science Press: Beijing, China, 2013. 
21. Ji, W.; Zhao, B. Contribution of outdoor-originating particles, indoor-emitted particles and indoor secondary organic aerosol (SOA) to residential indoor $\mathrm{PM}_{2.5}$ concentration: A model-based estimation. Build. Environ. 2015, 90, 196-205. [CrossRef]

22. Avery, C.L.; Mills, K.T.; Williams, R.; McGraw, K.A.; Poole, C.; Smith, R.L.; Whitsel, E.A. Estimating error in using residential outdoor $\mathrm{PM}_{2.5}$ concentrations as proxies for personal exposures: A meta-analysis. Environ. Health Perspect. 2010, 118, 673-678. [CrossRef]

23. Che, W.W.; Frey, H.C.; Lau, A.K.H. Comparison of sources of variability in school age children exposure to ambient $\mathrm{PM}_{2.5}$. Environ. Sci. Technol. 2015, 49, 1511-1520. [CrossRef]

24. Kearney, J.; Wallace, L.; MacNeill, M.; Xu, X.; VanRyswyk, K.; You, H.; Kulka, R.; Wheeler, A.J. Residential indoor and outdoor ultrafine particles in Windsor, Ontario. Atmos. Environ. 2011, 45, 7583-7593. [CrossRef]

25. Zhu, Y.; Yang, L.; Meng, C.; Yuan, Q.; Yan, C.; Dong, C.; Sui, X.; Yao, L.; Yang, F.; Lu, Y.; et al. Indoor/outdoor relationships and diurnal/nocturnal variations in water-soluble ion and $\mathrm{PAH}$ concentrations in the atmospheric $\mathrm{PM}_{2.5}$ of a business office area in Jinan, a heavily polluted city in China. Atmos. Res. 2015, 153, 276-285. [CrossRef]

26. Zhang, Y.; Cao, S.; Xu, X.; Qiu, J.; Chen, M.; Wang, D.; Guan, D.; Wang, C.; Wang, X.; Dong, B.; et al. Metals compositions of indoor $\mathrm{PM}_{2.5}$, health risk assessment, and birth outcomes in Lanzhou, China. Environ. Monit. Assess. 2016, 188, 325. [CrossRef]

27. Yang, Y.; Liu, L.; Xu, C.; Li, N.; Liu, Z.; Wang, Q.; Xu, D. Source apportionment and influencing factor analysis of residential indoor $\mathrm{PM}_{2.5}$ in Beijing. Int. J. Environ. Res. Public Health 2018, 15, 686. [CrossRef] [PubMed]

28. Bi, D.; Qiu, Y.; Cheng, H.; Zhou, Q.; Liu, X.; Chen, J.; Cui, X.; Liu, M.; Zhu, Z. Seasonal characteristics of indoor and outdoor fine particles and their metallic compositions in Nanjing, China. Build. Environ. 2018, 137, 118-126. [CrossRef]

29. Yang, Y.Y.; Liu, L.Y.; Guo, L.L.; Lv, Y.L.; Zhang, G.M.; Lei, J.; Liu, W.T.; Xiong, Y.Y.; Wen, H.M. Seasonal concentrations, contamination levels, and health risk assessment of arsenic and heavy metals in the suspended particulate matter from an urban household environment in a metropolitan city, Beijing, China. Environ. Monit. Assess. 2015, 187, 409. [CrossRef] [PubMed]

30. Gao, P.; Lei, T.; Jia, L.; Song, Y.; Lin, N.; Du, Y.; Feng, Y.; Zhang, Z.; Cui, F. Exposure and health risk assessment of $\mathrm{PM}_{2.5}$-bound trace metals during winter in university campus in Northeast China. Sci. Total Environ. 2017, 576, 628-636. [CrossRef] [PubMed]

31. Wang, F.; Zhou, Y.; Meng, D.; Han, M.; Jia, C. Heavy metal characteristics and health risk assessment of $\mathrm{PM}_{2.5}$ in three residential homes during winter in Nanjing, China. Build. Environ. 2018, 143, 339-348. [CrossRef]

32. Han, Y.; Li, X.; Zhu, T.; Lv, D.; Chen, Y.; Hou, L.A.; Zhang, Y.; Ren, M. Characteristics and relationships between indoor and outdoor $\mathrm{PM}_{2.5}$ in Beijing: A residential apartment case study. Aerosol Air Qual. Res. 2016, 16, 2386-2395. [CrossRef]

33. Huang, H.; Lee, S.-C.; Cao, J.-J.; Zou, C.-W.; Chen, X.-G.; Fan, S.-J. Characteristics of indoor/outdoor PM 2.5 and elemental components in generic urban, roadside and industrial plant areas of Guangzhou City, China. J. Environ. Sci. China 2007, 19, 35-43. [CrossRef]

34. Zhang, J.; Chen, J.; Yang, L.; Sui, X.; Yao, L.; Zheng, L.; Wen, L.; Xu, C.; Wang, W. Indoor PM 2.5 and its chemical composition during a heavy haze-fog episode at Jinan, China. Atmos. Environ. 2014, 99, 641-649. [CrossRef]

35. Nanjing Environmental Protection Agency. Nanjing Environmental Aspect Bulletin in 2016; Nanjing Environmental Protection Agency: Nanjing, China, 2017.

36. Shao, Z.; Bi, J.; Ma, Z.; Wang, J. Seasonal trends of indoor fine particulate matter and its determinants in urban residences in Nanjing, China. Build. Environ. 2017, 125, 319-325. [CrossRef]

37. USEPA. Risk Assessment Guidance for Superfund, Volume I: Human Health Evaluation Manual (Part F, Supplemental Guidance for Inhalation Risk Assessment); EPA-540-R-070-002; USEPA: Washington, DC, USA, 2009.

38. USEPA. Regional Screening Leve (RSL) Resident Air Supporting Table. 2011. Available online: https: / / www.epa.gov/risk/regional-screening-levels-rsls-generic-tables (accessed on 3 January 2019).

39. Hieu, N.T.; Lee, B.-K. Characteristics of particulate matter and metals in the ambient air from a residential area in the largest industrial city in Korea. Atmos. Res. 2010, 98, 526-537. [CrossRef]

40. Park, E.-J.; Kim, D.-S.; Park, K. Monitoring of ambient particles and heavy metals in a residential area of Seoul, Korea. Environ. Monit. Assess. 2008, 137, 441-449. [CrossRef] [PubMed] 
41. Wang, B.; Niu, H.; Liu, B.; Hu, X.; Ren, Z. The indoor-outdoor characteristics of water-soluble ion in $\mathrm{PM}_{2.5}$ in Tianjin wintertime. Environ. Sci. Pollut. Res. 2018, 25, 20985-20998. [CrossRef]

42. Hassanvand, M.S.; Naddafi, K.; Faridi, S.; Arhami, M.; Nabizadeh, R.; Sowlat, M.H.; Pourpak, Z.; Rastkari, N.; Momeniha, F.; Kashani, H.; et al. Indoor/outdoor relationships of $\mathrm{PM}_{10}, \mathrm{PM}_{2.5}$, and $\mathrm{PM}_{1}$ mass concentrations and their water-soluble ions in a retirement home and a school dormitory. Atmos. Environ. 2014, 82, 375-382. [CrossRef]

43. Wang, J.; Lai, S.; Ke, Z.; Zhang, Y.; Yin, S.; Zheng, J. Exposure assessment, chemical characterization and source identification of $\mathrm{PM}_{2.5}$ for school children and industrial downwind residents in Guangzhou, China. Environ. Geochem. Health 2014, 36, 385-397. [CrossRef] [PubMed]

44. Kulshrestha, A.; Bisht, D.S.; Masih, J.; Massey, D.; Tiwari, S.; Taneja, A. Chemical characterization of water-soluble aerosols in different residential environments of semi aridregion of India. J. Atmos. Chem. 2009, 62, 121-138. [CrossRef]

45. Seguin, A.M.; Norman, A.-L.; Eaton, S.; Wadleigh, M. Seasonality in size segregated biogenic, anthropogenic and sea salt sulfate aerosols over the North Atlantic. Atmos. Environ. 2011, 45, 6947-6954. [CrossRef]

46. Widory, D. Lead isotopes decipher multiple origins within single $\mathrm{PM}_{10}$ samples in the atmosphere of Paris. Isot. Environ. Health Stud. 2006, 42, 97-105. [CrossRef]

47. Kristensen, L.J. Quantification of atmospheric lead emissions from 70 years of leaded petrol consumption in Australia. Atmos. Environ. 2015, 111, 195-201. [CrossRef]

48. Massey, D.; Kulshrestha, A.; Masih, J.; Taneja, A. Seasonal trends of $\mathrm{PM}_{10}, \mathrm{PM}_{5.0}, \mathrm{PM}_{2.5}$ \& $\mathrm{PM}_{1.0}$ in indoor and outdoor environments of residential homes located in North-Central India. Build. Environ. 2012, 47, 223-231.

49. Madany, I.M.; Akhter, M.S.; Jowder, O.A.A. the correlations between heavy-metals in residential indoor dust and outdoor street dust in Bahrain. Environ. Int. 1994, 20, 483-492. [CrossRef]

50. Zhang, F.; Wang, Z.W.; Cheng, H.R.; Lv, X.P.; Gong, W.; Wang, X.M.; Zhang, G. Seasonal variations and chemical characteristics of $\mathrm{PM}_{2.5}$ in Wuhan, central China. Sci. Total Environ. 2015, 518-519, 97-105. [CrossRef] [PubMed]

51. Schwartz, J. Air pollution and children's health. Pediatrics 2004, 113, 1037-1043.

52. Kurt-Karakus, P.B. Determination of heavy metals in indoor dust from Istanbul, Turkey: Estimation of the health risk. Environ. Int. 2012, 50, 47-55. [CrossRef]

53. Zhang, N.; Han, B.; He, F.; Xu, J.; Niu, C.; Zhou, J.; Kong, S.; Bai, Z.; Xu, H. Characterization, health risk of heavy metals, and source apportionment of atmospheric $\mathrm{PM}_{2.5}$ to children in summer and winter: An exposure panel study in Tianjin, China. Air Qual. Atmos. Health 2015, 8, 347-357. [CrossRef]

54. Kulshrestha, A.; Massey, D.D.; Masih, J.; Taneja, A. Source characterization of trace elements in indoor environments at urban, rural and roadside sites in a semi arid region of India. Aerosol Air Qual. Res. 2014, 14, 1738-1751. [CrossRef]

(C) 2019 by the authors. Licensee MDPI, Basel, Switzerland. This article is an open access article distributed under the terms and conditions of the Creative Commons Attribution (CC BY) license (http://creativecommons.org/licenses/by/4.0/). 